ORIGINAL ARTICLE, MEDICINE

\title{
Diagnostic Dilemmas in Hepatitis C Virus Infection for Hemodi- alysis Patients
}

\author{
Radka T. Komitova ${ }^{1,2}$, Maria V. Atanasova ${ }^{3}$, Toska A. Pavlova4, Monica Sh. Nyagolov' ${ }^{5}$, Aneta V. \\ Ivanova $^{5}$ \\ ${ }^{1}$ Department of Infectious Diseases, Parasitology and Tropical Medicine, Faculty of Medicine, Medical University of Plovdiv, Plovdiv, \\ Bulgaria \\ ${ }^{2}$ Clinic of Infectious Diseases, St George University Hospital, Plovdiv, Bulgaria \\ ${ }^{3}$ Department of Microbiology and Immunology, Faculty of Pharmacy, Medical University of Plovdiv, Plovdiv, Bulgaria \\ ${ }^{4}$ Hemodialysis Unit, St George University Hospital, Plovdiv \\ ${ }^{5}$ Clinic of Gastroenterology, Laboratory of Porphyrias and Molecular Diagnostics of Liver Diseases, St Ivan Rilski University Hospital, Sofia
}

\section{Correspondence:}

Radka T. Komitova, Department of Infectious Diseases, Parasitology and Tropical Medicine, Faculty of Medicine, Medical University of Plovdiv, 15A Vassil Aprilov Blvd., 4002 Plovdiv, Bulgaria

E-mail: radkakomitova@yahoo.com Tel.: +359882495800

Received: 15 Oct 2015

Accepted: 20 Dec 2016

Published Online: 09 Jan 2017

Published: 27 March 2017

Key words: hemodialysis, viral hepatitis, hepatitis $C$ virus, prevalence, nosocomial transmission

Citation: Komitova RT, Atanasova MV, Pavlova TZ, Nyagolov MS, Ivanova AV. Diagnostic dilemmas in hepatitis $C$ virus infection for hemodialysis patients.

Folia Medica 2017;59(1):70-77. doi: 10.1515/folmed-2017-0012
Background: Hepatitis C virus (HCV) is a leading cause of chronic hepatitis in dialysis patients. The diagnosis of HCV infection in these patients is predominantly based on laboratory tests because of the specificity of the clinical course of the disease.

Aim: The present prospective study aimed at determining very accurately the prevalence rate of $\mathrm{HCV}$ infection in patients on dialysis by simultaneously testing them for anti-HCV and for HCV RNA levels.

Materials and methods: For the present cross-sectional longitudinal study we recruited and followed up 93 patients from St George University Hospital Hemodialysis Unit between July 2013 and December 2014. All patients were tested for anti-HCV and HCV RNA. The anti-HCV negative patients were tested for anti-HCV and HCV RNA at least twice at intervals of 6 months or more (up to 12 months). Anti-HCV antibodies were identified using a third generation ELISA assay. Commercial kits for real-time polymerase chain reaction (RT-PCR) were used to detect HCV RNA in the plasma and mononuclear cells. Aminotransferase and gammaglutamyl transpeptidase levels were studied to find if liver inflammation was present.

Results: The total seroprevalence in 68 patients was $20.6 \%$ (14). Of these, 10 patients were viremic (HCV RNA+/anti-HCV+), and 4 patients (5.9\%) had discordant results (anti-HCV+/HCV RNA-). Acute hepatitis was detected in one patient. Duration of dialysis in HCV viremic patients was longer than that in aviremic patients $(p=0.005)$.

Conclusions: The present study suggests that HCV infection in dialysis patients can be diagnosed more accurately if these patients are tested using two diagnostic methods - a serological test and a biomolecular assay. Further studies with larger sample size may prove the feasibility of such approach for all dialysis patients in this country.

\section{BACKGROUND}

Hepatitis $\mathrm{C}$ virus (HCV) is the major culprit causing chronic hepatitis in patients with terminal chronic kidney disease.

Improved dialysis procedures, extensive use of erythropoietin, donor blood screening using more rigorous methods, and strict adherence to standard precautionary measures have reduced HCV infection occurrence rate in dialysis patients but sadly fell short of eliminating the disease among them. At present, the main mode of $\mathrm{HCV}$ infection transmission is nosocomial. ${ }^{1}$

$\mathrm{HCV}$ prevalence varies considerably for the different hemodialysis centres throughout the world - it is very low in the developed countries, especially in Germany (6.1\%) and the United Kingdom (3.9\%), but it is substantially high in the Middle East countries (Kuwait 71\%). ${ }^{2-4}$

$\mathrm{HCV}$ infection in dialysis patients tends to run an asymptomatic course with mild changes in the 
laboratory and morphology parameters. ${ }^{5,6}$ Hence the importance of laboratory studies for patients with $\mathrm{HCV}$ infection. Routine laboratory diagnosis of HCV infection is based on the specific antibodies identified by an immunoenzyme assay (ELISA). All anti-HCV positive results have to be verified by detecting HCV RNA levels (viral load) in blood, commonly using the polymerase chain reaction (PCR) technique. The quantitative RT-PCR-based assay is among the most highly sensitive tests available with a very low detection limit of $\mathrm{HCV}$ RNA - 10-50 IU/ml. ${ }^{7}$ That is the reason why most researchers recommend that a combination of ELISA and PCR be used in such cases as the most highly sensitive diagnostic approach to $\mathrm{HCV}$ infection in dialysis patients. ${ }^{8,9}$

Early diagnosis of this condition has more than just epidemiological significance. Early diagnosis is crucial when it comes to choosing the therapy for $\mathrm{HCV}$-infected candidates for kidney transplantation. Unlike the patients not receiving pretransplantation $\mathrm{HCV}$ therapy, those patients treated for $\mathrm{HCV}$ prior to transplantation develop very rarely posttransplantation diabetes and glomerulonephritis of the graft. $^{10-12}$

Lately, a special clinical entity has been reported - occult hepatitis $\mathrm{C}$ virus infection. The viruses in this form of the disease are detected in the peripheral blood mononuclear cells (PBMCs) and/ or in hepatocytes but not in the blood. ${ }^{13}$ There is, however, quite scanty evidence for this form of the disease in hemodialysis patients. ${ }^{14}$

There are only few reports of $\mathrm{HCV}$ infection in hemodialysis patients in Bulgaria. ${ }^{15,16}$ In 2004, 25.2\% of all dialysis patients in Bulgaria were anti-HCV $(+)$ while in the following years the seropositivity rate fell down to $11 \%$ in 2009 and to $9.6 \%$ in $2012 .{ }^{17,18}$ In Bulgaria, screening dialysis patients is routinely conducted using serological tests, with biomolecular assays being used only in single cases.

\section{AIM}

The present prospective study aimed at finding the prevalence of $\mathrm{HCV}$ infection in hemodialysis patients by testing patients for both the anti-HCV and HCV RNA levels.

\section{MATERIALS AND METHODS}

\section{Patients (study Design)}

The present cross-sectional study included 93 patients recruited from the Hemodialysis Unit in
St George University Hospital, where they were treated between July 2013 and December 2014. Of these, 17 (68) patients were included in a 2007 cross-sectional study.

Inclusion criteria: patients were eligible for registry enrolment if they were on hemodialysis for end-stage chronic renal failure, no younger than 18 years, and had given a written informed consent for participation. Patients on peritoneal dialysis were excluded from the study.

The participants were registered in the study with their demographic and clinical characteristics - sex, age, ethnic group, duration of dialysis, diagnosis of the disease that caused the end-stage chronic renal failure, number of blood transfusions, and previous kidney transplantation.

At baseline, immediately after inclusion into the study, these patients were tested for anti-HCV and HCV RNA. Those that tested positive were retested using another blood sample. In the second phase of the study, the anti-HCV seronegative patients were followed up clinically and tested for anti-HCV and HCV RNA at least twice at an interval of 6 and more than 6 months (up to 12 months).

Plasma and sera were extracted from the blood samples collected from every patient prior to dialysis. The sera were divided into aliquots and used for biochemical and serological tests while the plasma was stored at $-80^{\circ} \mathrm{C}$ until tested for HCV RNA.

To exclude fluctuating viremia, the patients positive for anti-HCV but negative for HCV RNA were retested two more times for HCV RNA.

The patients who were serum HCV RNA negative at two tests were retested for HCV RNA in the PBMCs to detect occult $\mathrm{HCV}$ infection, regardless of whether or not they had anti-HCV antibodies. For this purpose serum was separated from blood immediately after taking the blood sample, stored frozen, and transported to the Laboratory of Molecular Diagnostics of Liver Diseases in St Ivan Rilski University Hospital, Sofia.

\section{LABORATORY STUDIES}

\section{Detection of anti-HCV antibodies}

ELISA and commercial diagnostic kits (CE, IVD) Bioelisa HCV 5.0 (Biokit, Spain) were used to detect anti-HCV antibodies. All positive results were confirmed with an alternative diagnostic kit (DiaPro, Italy). The studies were performed in the Laboratory of Virology in St George University Hospital, Plovdiv. 
Detection of HCV RNA in plasma and in peripheral blood mononuclear cells (PBMCs)

Quantitative assessment of plasma HCV RNA was performed using Bosphore ${ }^{\circledR} \mathrm{HCV}$ Quantification kit v1, which uses a RT-PCR assay with detection limit of $25 \mathrm{IU} / \mathrm{ml}$ (Anatolia Geneworks, CE, IVD). For PBMCs - after separation of the cells to the initial quantity of about $5.10^{6}$ and isolation of the common RNA, we used the HCV LC RT-PCR method that can be used with LightCycler 1.5 diagnostic instrument (Roche, Switzerland) (Abe $\mathrm{M}$ et al.) with detection limit of 27 genomic copies (about 9 $\mathrm{IU} / \mathrm{ml}$ ). Virus genotyping was performed using the same method (Abe $\mathrm{M}$ et al.). The molecular and biological studies were performed in the Laboratory of Molecular Diagnostics of Liver Diseases in St Ivan Rilski University Hospital, Sofia.

\section{BIOCHEMICAL STUDIES}

Alanine aminotransferase (ALT), aspartate aminotransferase (AST), and gamma glutamyl transpeptidase (GGT) were identified by the Central Clinical Laboratory of St George University Hospital, Plovdiv using common automated spectrophotometric methods. The tests were done at intervals of 6 months and if needed.

\section{DiALYSIS PROCEDURE}

Patients were dialyzed for 4 hours thrice weekly. The anti-HCV positive patients were given dialysis in dedicated rooms. The protocol followed in the study was in accordance with the ethical principles of the Declaration of Helsinki and approved by the Ethics Committee of the Medical University in Plovdiv. All participants gave their written informed consent to be entered into the study.

\section{Statistical ANALYSIS}

$\chi^{2}$ was used to find the relationship between the qualitative variables; Mann-Whitney $U$ test was used to find the relationship between the quantitative variables. A value of $p<0.05$ was considered statistically significant. The analysis was performed using SPSS v. 16.0.

\section{RESULTS}

The inclusion criteria were met by 68 patients. All the other patients dropped out of the study because of either a lethal outcome or a transfer to another dialysis centre. Table 1 presents the basic demographic, clinical and epidemiological characteristics of the participants. The mean age of the patients was 57 years (range 18 to 84 ); men predominated
$(51.75 \%)$ and the median duration of dialysis was 54 months (range $6-365$ ). Forty-four patients (64.7\%) received blood transfusions (range from 1 to 27). The reason to start hemodialysis for about half of the patients with end-stage chronic renal disease were chronic glomerulonephritis and chronic pyelonephritis.

Table 1. Major characteristics of patients on dialysis $(n=68)$.

\begin{tabular}{lc}
\hline Characteristics & $\mathbf{n}, \mathbf{( \% )}$ \\
\hline Age (yrs) & $57,($ range $18-84)$ \\
Sex - men & $51,(75 \%)$ \\
Duration of dialysis (months) & $54,($ range 6-365) \\
With blood transfusions & $44,(64.7 \%)$ \\
With renal transplantation & $1,(1.5 \%)$ \\
Diagnosis & \\
CGN $^{1}$ & $18,(26.5 \%)$ \\
CPN $^{2}$ & $13,(19.1 \%)$ \\
Polycystic kidney disease & $7,(10.3 \%)$ \\
Diabetic nephropathy & $5,(7.3 \%)$ \\
Other diagnoses & \\
Unrecognized & $6,(8.8 \%)$ \\
\hline
\end{tabular}

${ }^{1} \mathrm{CGN}$ : chronic glomerulonephritis, ${ }^{2} \mathrm{CPN}$ : chronic pyelonephritis, ${ }^{3}$ Other diagnoses: myeloma kidney, hypertension kidney disease

At baseline 13 patients were anti-HCV positive with 10 of these HCV RNA positive, that is, they were viremic. Another four were HCV RNA negative - they had discordant results (anti-HCV positive / HCV RNA negative). Evidence of acute HCV hepatitis was found in one of the ten viremic patients. He was HCV RNA positive and anti-HCV negative at baseline but 3 months later we detected seroconversion and intensification of viremia. The same patient had negative HCV markers in 2007. Phylogenetic analysis was not performed for logistic reasons.

There were a total of $14(20.6 \%)$ anti-HCV positive patients, $10(14.7 \%)$ viremic patients and $4(5.9 \%)$ aviremic patients. Table 2 presents the HCV markers of 68 patients. HCV genotype 1 was identified in the ten viremic patients.

Three of the viremic patients were found positive 
Table 2. HCV markers in patients on hemodialysis $(n=68)$.

\begin{tabular}{lccc}
\hline & HCV RNA $(+)$ & HCV RNA $(-)$ & Total \\
\hline ELISA $(+)$ & $10(14.7 \%)$ & $4(5.9 \%)$ & $14(20.6 \%)$ \\
ELISA $(-)$ & 0 & $54(79.4 \%)$ & $54(79.4 \%)$ \\
Total & $10(14.7 \%)$ & $58(85.3 \%)$ & $68(100 \%)$ \\
\hline
\end{tabular}

in 2007 - these included a patient placed again on dialysis after rejection of the transplanted kidney. Another patient with fluctuating levels of viremia was found to have no evidence of HCV RNA at the first test and then the patient's second test found the HCV RNA level to be $1950 \mathrm{IU} / \mathrm{ml}$. One patient was found to have low level viremia, which was not detected in the subsequent two tests for $\mathrm{HCV}$ RNA. Such a result was considered false positive.

Thiry-seven patients were tested for HCV RNA in the PBMCs and none were found to have any evidence of occult $\mathrm{HCV}$ hepatitis.

The four anti-HCV positive / HCV RNA negative patients were retested for anti-HCV and HCV RNA

Comparing the characteristics of viremic and aviremic patients we found that the viremic patients had longer duration of dialysis $(\mathrm{p}=0.005)$. Also the mean ALT $(p=0.015)$, AST $(p=0.007)$ and GGT $(p=0.012)$ were higher for the viremic patients yet were within the reference range (Table 3 ).

\section{DISCUSSION}

This is the first prospective study in Bulgaria in which patients on dialysis have been tested simultaneously for anti-HCV and HCV RNA levels. We found 10 patients with viremia (14.6\% prevalence) and 1 patient with acute hepatitis $(0.015 \%)$. In another four patients $(0.6 \%)$, the only $\mathrm{HCV}$ marker was anti-HCV positive antibodies. If these patients had been tested only serologically, which is the routine practice in Bulgaria for dialysis patients, they would have been misdiagnosed as infected.

The HCV prevalence we found in this study was high; it was 10 times as high as that in the general Bulgarian population. ${ }^{19}$ It was also higher than the prevalence for the entire dialysis population over the last years: $11 \%$ for 2009 and $9.6 \%$ for 2012 . We used two diagnostic methods - serological tests and biomolecular assays, and tested every patient with these two methods at least twice. This was done to reduce to a minimum the occurrence of false positive or false negative results and to assess very accurately the prevalence rate.

The characteristics of the viremic patients were not much different from the ones available up to now: they were with asymptomatic course and negligible

Table 3. Correlation between demographic characteristics, parenteral risk, aminotransferases and HCV RNA positive status of the patients $(n=68)$.

\begin{tabular}{lccc}
\hline Parameters & $\begin{array}{c}\text { HCV RNA (+) } \\
(\mathbf{n = 1 0 )}\end{array}$ & $\begin{array}{c}\text { HCV RNA (-) } \\
(\mathbf{n = 5 8})\end{array}$ & p \\
\hline Mean age (yrs) & $53(26-82)$ & $56(18-84)$ & 0.709 \\
Sex (men to women ratio) for the respective group & 4.00 & 1.32 & 0.290 \\
Duration of dialysis (months) & $118(30-324)$ & $52(6-355)$ & 0.005 \\
Blood transfusions (average number) & $5(0-18)$ & $3(0-27)$ & 0.411 \\
AST (IU/L)* & $22.4 \pm 4.1$ & $13.4 \pm 1.1$ & 0.007 \\
ALT (IU/L)* & $23.8 \pm 7.2$ & $14.5 \pm 3.7$ & 0.015 \\
GGT (IU/L)* & $49.7 \pm 9.2$ & $28.2 \pm 2.2$ & 0.012 \\
\hline
\end{tabular}

$*$ mean \pm SEM (mean \pm standard error)

Reference ranges: aspartate aminotransferase $(\mathrm{AST})=0$-36 IU/1, alanine aminotransferase (ALT)=0-45 IU/1, gamma glutamyl transpeptidase $(\mathrm{GGT})=0-50 \mathrm{IU} / 1$ 
changes in the liver established in laboratories.

It is of particular significance that many researchers have reported lower serum levels of aminotransferases in dialysis patients than those in individuals with normal renal function. Although difficult to account for, this finding is believed to be probably related to vitamin B6 deficiency and to some uremic toxins. For this reason new lower reference values have been suggested: $18 \mathrm{IU} / 1$ for AST and $16 \mathrm{IU} / 1$ for ALT. If assessed by these criteria, the enzyme levels are high in most patients..$^{20,21}$ The levels we found were also higher than the lower reference values $-\mathrm{ALT}>16 \mathrm{IU} / 1$ and AST $>18 \mathrm{IU} / 1$ in 7 (70\%) viremic patients.

As found by many researchers, the major risk factors are dialysis duration and the number of blood transfusions; a complementary risk factor is renal transplantation. ${ }^{22,23}$ These factors are interdependent, that is, the longer the treatment the greater the likelihood of more blood transfusion. An independent risk factor for $\mathrm{HCV}$ infection in the present study is the duration of dialysis procedure.

A patient with renal transplantation in 1998, 10 years after starting dialysis, presents an interesting case. In 2004, due to transplant rejection, the patient was placed on dialysis again. There was no evidence of any anti-HCV tests for this patients between 1998 and 2004. Screening organ donors for $\mathrm{HCV}$ in the European Union countries started in 1994 which makes it highly unlikely for the graft to our patient to have been tested for that. The prevalence of anti-HCV(+) for patients resuming dialysis because of a rejected graft is greater than that of patients just starting dialysis treatment. As suggested by other researchers, the infection in our case is quite likely to have occurred after blood transfusions either due to nosocomial transmission or via the graft. ${ }^{23}$

What assays are used to determine HCV can impact the prevalence rate measured. The condition was found to be underdiagnosed back in the early 1990s using the first and second generation of ELISA as a result of the lesser sensitivity of these tests. The currently used third generation ELISA has high sensitivity and specificity. And yet, some immunodeficient dialysis patients (such as the diabetics) may remain anti-HCV negative even after they have been infected. ${ }^{24}$

Antibodies are however useless in differentiating between current and past infection. The second diagnostic method, the biomolecular method, is a confirmatory test used to determine the levels of
HCV RNA. A number of techniques are available at present and among the most sensitive ones is RT-PCR. The RT-PCR we used has a very low detection level - $25 \mathrm{IU} / \mathrm{ml}$. Retesting for HCV RNA allowed us to detect a false positive result in one patient and fluctuating viremia in another patient.

Using PCR, we were also able to diagnose a case of acute hepatitis $\mathrm{C}$ four months before seroconversion. The patient in question had ALT concentrations within normal range but was tested only twice. In acute HCV infection ALT level begins to increase 2 to 8 weeks after exposure. Symptoms usually appear 3-12 weeks (mean 7 weeks) after infection, and anti-HCV become positive either simultaneously or with a little delay. ${ }^{25}$ The aminotransferase level might be slightly elevated and transitory. ${ }^{1}$ This has a practical significance since for all cases in which there is unexplained ALT increase, even a very slight increase, acute HCV infection should be suspected. It is only by monthly ALT testing of non-infected patients that an ALT increase could be detected. We couldn't find whether this case of acute hepatitis $\mathrm{C}$ infection was a result of a nosocomial infection because phylogenetic analysis was not possible.

Occult hepatitis $\mathrm{C}$ is a peculiar form of $\mathrm{HCV}$ infection with yet unclear significance and a disputed role. In a study of 103 patients on chronic dialysis, Barril et al. ${ }^{14}$ found $\mathrm{HCV}$ in the PBMCs in $45 \%$ of the patients with abnormal liver enzymes. Other researchers have found that $\mathrm{HCV}$ does not relapse in patients cured of chronic hepatitis $\mathrm{C}$ and with transplanted organs in spite of the long-term immunosuppressive therapy they received. To find the clinical significance and the epidemiologic risk of transmission of occult HCV infection, Baid-Agrawal et al. ${ }^{26}$ recommend long-term testing of populations with high incidence.

Four patients with discordant results (anti-HCV positive / HCV RNA negative) are worth a special attention. Their results can be associated with fluctuating viremia, previous exposure to $\mathrm{HCV}$ or could be biologically false positive. The triple HCV RNA negative results for the patients' plasma exclude the first possibility. They are unprotected although they do not carry epidemiological risk. They could also be accounted for by a previous acute hepatitis $\mathrm{C}$ infection that resolved spontaneously. Recovery after acute hepatitis $\mathrm{C}$ of patients on dialysis is, however, very rare in comparison with the general population. After viruses clear, specific antibodies may disappear and persist thus for several years, and could very rarely be found in low concentrations 
over many years. ${ }^{27}$ In these cases, however, $\mathrm{HCV}$ RNA is found in PBMCs which we did not find in our study contingent. ${ }^{28}$ It is, however, not impossible to find HCV RNA in the liver tissue. To exclude a third possibility, biologically false positive results, it is necessary to have a retest with ELISA, commonly obtained from another manufacturer, using antigens of different immunodominant regions. In cases of biologically false positive results, when one and same sample is tested using a different ELISA assay, the positive result is usually not subjected to testing. This could be due to the great variability of the individual immune response to different antigens in the test kits or different vectors in cloning recombinant proteins. ${ }^{29,30}$ Use of a different ELISA assay as a complementary test after positive sample in screening is introduced in the algorithm for HCV testing of the United Kingdom (National Standard Method VSOP5i5,2005). Such an algorithm is recommended also by CDC (Center for Disease Control and Prevention) in 2013. ${ }^{31}$

We would like to note some of the limitations of the present study, such as small size of population sample, irregular incomplete liver function tests, no data for HCV status prior to beginning of dialysis. The great turnover of dialysis patients, discarding some due to lethal outcome, a transfer to a different dialysis center and inclusion of new patients make it difficult to have a thorough medical documentation. Nevertheless, we found very accurately the HCV status of 68 patients on dialysis - they had a prevalence of $14.7 \%$ rather than $20.6 \%$ that would have come out if routinely screened with ELISA.

In 2008, the working group KDIGO (Kidney Disease: Improving Global Outcomes) published the first clinical practice guidelines dealing with different aspects of HCV infection in end-stage chronic renal failure patients. It is recommended that the anti-HCV screening for HCV negative patients be done at intervals of 6 to 12 months. For maximum elimination of false positive or false negative results, the screening method is determined dependent upon the prevalence of $\mathrm{HCV}$ infection in the respective dialysis center. Serological tests are recommended in low infection prevalence, while nucleic acid amplification tests are to be used in cases with high prevalence of the infection. ${ }^{10}$

\section{CONCLUSION}

The results of the present study suggest that a higher accuracy of diagnosing HCV infection in dialysis patients can be achieved if two diagnostic methods - a serological test and a biomolecular assay - are used simultaneously. To see if such approach is feasible for all dialysis patients in this country further studies including a larger sample size are required.

\section{ACKNOWLEDGEMENTS}

The study was funded by the Ministry of Education project $05 / 2013$. The authors wish to extend their gratitude to the team of the Hemodialysis Center, the patients for their willing participation, Dr Tanzina Haque from the Department of Virology in the Royal Free Hospital London for the serum testing using MonoLiza. We also would like to thank Assoc. Professor N. Mateva for her assistance in the statistical analysis of the results.

\section{REFERENCES}

1. Izopet J, Sandres-Sauné K, Kamar N, et al. Incidence of HCV infection in French hemodialysis units: a prospective study. J Med Virol 2005;77(1):70-6.

2. Hinrichsen H, Leimenstoll G, Stegen G, et al. Prevalence and risk factors of hepatitis $\mathrm{C}$ virus infection in haemodialysis patients: a multicentre study in 2796 patients. Gut 2002;51(3):429-33.

3. Jadoul M, Poignet JL, Geddes C, et al. The changing epidemiology of hepatitis $\mathrm{C}$ virus (HCV) infection in haemodialysis: European Multicentre Study. Nephrol Dial Transplant 2004;19(4):904-9.

4. Kapoor M, el-Rashaid K, al-Mufti S, et al. Is dialysis environment more important than blood transfusion in transmission of hepatitis $\mathrm{C}$ virus during haemodialysis? [letter]. Vox Sang 1993;65:331.

5. Rampino T, Arbustini E, Gregorini M, et al. Hemodialysis prevents liver disease caused by hepatitis $\mathrm{C}$ virus: role of hepatocyte growth factor. Kidney Int 1999;56(6):2286-91.

6. Fabrizi F, Lunghi G, Finazzi S, et al. Decreased serum aminotransferase activity in patients with chronic renal failure: impact on the detection of viral hepatitis. Am J Kidney Dis 2001;38(5):1009-15.

7. Urbánek P. Viral hepatitis infections in chronic kidney disease patients and renal transplant recipients. Kidney Blood Press Res 2012;35(6):454-67.

8. Schneeberger PM, Keur I, van der Vliet W, et al. Hepatitis C infection in dialysis centers in The Netherlands: a national survey by serological and molecular methods. J Clin Microbiol 1998:36:1711-5.

9. Bukh J, Wantzin P, Krogsgaard K, et al. High prevalence of hepatitis $\mathrm{C}$ virus (HCV) RNA in dialysis patients: failure of commercially available antibody tests to identify a significant number of patients with $\mathrm{HCV}$ infection. Copenhagen Dialysis HCV Study 
Group. J Infect Dis 1993;168(6):1343-8.

10. KDIGO. Kdigo Practical Guidelines for the prevention, diagnosis, evaluation and treatment of hepatitis $\mathrm{C}$ in chronic kidney disease. Kidney Int 2008;73:S1-99.

11. Cruzado JM, Casanovas-Taltavull T, Torras J, et al. Pretransplant interferon prevents hepatitis $C$ virus-associated glomerulonephritis in renal allografts by HCV-RNA clearance. Am J Transplant 2003;3(3):357-60.

12. Gursoy M, Köksal R, et al. Impact of HCV infection on development of post-transplantation diabetes mellitus in renal allograft recipients. Transplant Proc 2000;32(3):561-2.

13. Castillo I, Pardo M, Bartolomé J, et al. Occult hepatitis $\mathrm{C}$ virus infection in patients in whom the etiology of persistently abnormal results of liver-function tests is unknown. J Infect Dis 2004;189(1):7-14.

14. Barril G, Castillo I, Carreño V. Evidence of occult hepatitis $\mathrm{C}$ virus infection in hemodialysis patients. Am J Am Soc Nephrol 2008;19:2288-92.

15. Todorov V, Boneva R, Ilieva P, et al. High prevalence of hepatitis $\mathrm{C}$ virus infection in one dialysis center in Bulgaria. Nephron 1998;79:222-3.

16. Vladimirova N. [Epidemic outbreak of Hepatitis B and $\mathrm{C}$ in the center of hemodialysis.] Nosocomial infections 2009;6:78-95. [Bulgarian]

17. Vazelov E, Mushekov V. Sero-epidemiology of viral hepatitis in haemodialysis and control measures. VHPB-country meeting on "Burden and prevention of viral hepatitis in Bulgaria": Sofia, 24-25 March 2011.

18. Vazelov E, Georgieva I, Lubih M, et al. Reduction of the incidence of $\mathrm{HBV}$ and $\mathrm{HCV}$ infection in patients treated in the Dialysis Clinic at Alexandrovska University Hospital. Nephrologia, dializa y transplantacia 2012;4:18. [Bulgarian]

19. Atanasova MV, Haydouchka IA, Zlatev SP, et al. Prevalence of antibodies against hepatitis $\mathrm{C}$ virus and hepatitis B coinfection in healthy population in Bulgaria. A seroepidemiological study. Minerva Gastroenterol Dietol 2004;50(1):89-96.
20. Espinosa M, Martin-Malo A, Alvarez de Lara MA, et al. High ALT levels predict viremia in anti-HCVpositive HD patients if a modified normal range of ALT is applied. Clin Nephrol 2000;54(2):151-6.

21. Guh JY, Lai YH, Yang CY, et al. Impact of decreased serum transaminase level on the evaluation of viral hepatitis in hemodialysis patients. Nephron 1995;69:459-65.

22. Di Lallo D, Miceli M, Petrosillo N, et al. Risk factor of hepatitis $\mathrm{C}$ virus infection in patients on hemodialysis: multivariate analysis bases on a dialysis register in central Italy. Eur J Epidemiol 1999; 15:11-4.

23. Periera BJ, Levey AS. Hepatitis C virus infection in dialysis and renal transplantation. Kidney Intern 1997;51:981-99.

24. Hoofnagle JH. Course and outcome of hepatitis C. Hepatology 2002;36 (5 Suppl 1):S21-29.

25. Takashi A, Kazuhiko H, Michio I, et al. 2011 Japanese society for dialysis therapy guidelines for the treatment of hepatitis $\mathrm{C}$ virus infection in dialysis patients. Ther Apher Dial 2012;16:289-310.

26. Baid-Agrawal S, Schnidler R, Reinke P, et al. Prevalence of occult hepatitis $\mathrm{C}$ infection in chronic hemodialysis and kidney transplant patients. J Hepatol 2014;60:928-33.

27. Lefrere J, Guiramand S, Lefrere F, et al. Full or partial seroreversion in patients infected by hepatitis C virus. J Infect Dis 1997;175:316-22.

28. Pham T, MacParland S, Mulrooney P, et al. Hepatitis $\mathrm{C}$ virus persistence after spontaneous or treatment-induced resolution of hepatitis C. J Virol 2005;78:5867-74.

29. Zachary P, Ullmann M, Djeddi S, et al. Evaluation of three commercially available hepatitis $\mathrm{C}$ virus antibody detection assays under the conditions of a clinical virology laboratory. J Clin Virol 2005;34:207-10.

30. Vermeersch P, Rants M, Lagrou K. Validation strategy for HCV antibody testing with two enzyme immunoassays in a routine clinical laboratory. $\mathrm{J}$ Clin Virol 2008;42:394-8.

31. Testing for HCV Infection: an update of guidance for clinicians and laboratorians. Morbidity and Mortality Weekly Report 2013;62:362-5. 


\title{
Диагностические дилеммы при гепатит С вирусной инфекции у па- циентов на гемодиализе
}

\author{
Радка Т. Комитова ${ }^{1,2}$, Мария В. Атанасова ${ }^{3}$, Тоска А. Павлова 4 , Моника Ш. Няголов ${ }^{5}$, \\ Анета В. Иванова ${ }^{5}$ \\ ${ }^{1}$ Кафедра инфекционных болезней, паразитологии и тропической медицины, Факультет медицины, Медицинский уни- \\ верситет-Пловдив, Пловдив, Болгария \\ ${ }^{2}$ Клиника инфекционных болезней, Университетская больница „Св. Георгий”, Пловдив, Болгария \\ ${ }^{3}$ Кафедра микробиологии и иммунологии, Факультет фармации, Медицинский университет-Пловдив, Пловдив, Болгария \\ ${ }^{4}$ Отделение гемодиализа, Университетская больница "Св. Георгий", Пловдив, Болгария \\ ${ }^{5}$ Клиника гастроэнтерологии, Лаборатория порфирии и молекулярной диагностики заболеваний печени, Университетская \\ больница „Св. Иван Рилски", София, Болгария
}

\author{
Адрес для корреспонденции: \\ Радка Т. Комитова, Кафедра \\ инфекционных болезней, \\ паразитологии и тропической \\ медицины, Факультет \\ медицины, Медицинский \\ университет-Пловдив, бул. \\ Васил Априлов 15A, 4002 \\ Пловдив, Болгария \\ E-mail: radkakomitova@yahoo.com \\ Тел: +359882495800
}

Дата получения: 15 октября 2015

Дата приемки: 20 декабря 2016 Дата онлайн публикации: 09 января 2017

Дата публикации: 27 марта 2017

Ключевые слова: гемодиализ, вирусный гепатит, вирус гепатита $C$, распространение, внутрибольничная передача инфекции

Образец цитирования: Komitova RT, Atanasova MV, Pavlova TZ, Nyagolov MS, Ivanova AV. Diagnostic dilemmas in hepatitis $C$ virus infection for hemodialysis patients.

Folia Medica 2017;59(1):70-77. doi: 10.1515/folmed-2017-0012
Введение: Вирус гепатита С (HCV) является основной причиной хронического гепатита у пациентов на гемодиализе. Диагноз HCV инфекции у данной категории пациентов базируется главным образом на лабораторных исследованиях ввиду специфики клинического хода заболевания.

Цель: Настоящее проспективное исследование имеет целью определить наиболее точным образом скорость распространения HCV инфекции у пациентов на диализе с параллельным исследованием на предмет уровней антиHCV и HCV- PHK.

Материалы и методы: В целях данного поперечного /срезового/ долгосрочного исследования были отобраны и прослежены 93 пациента Отделения гемодиализа Университетской больницы «Св. Георгий» в период с июля 2013 по декабрь 2014. Все пациенты были обследованы на предмет анти- HCV и HCV- PHК. Пациенты с отрицательными результатами на предмет анти- HCV были обследованы на предмет анти- HCV и HCV- PHК не менее двух раз в протяжении 6 месяцев или дольше (до 12 месяцев). Анти - HCV антителата были установлены с применением ELISA теста третьего поколения. Были использованы комплекты для исследования полимеразной цепной реакции (RT-PCR) B реальном времени на предмет обнаружения HCV- PHК в плазме и мононуклеарных клетках. Были исследованы уровни аминотрансферазы и гамма-глутамил транспептидазы с целью установления наличия или отсутствия воспаления печени.

Результаты: Общая серологическая распространённость у 68 пациентов составляла 20.6\% (14). Из них 10 пациентов являлись виремическими (HCV

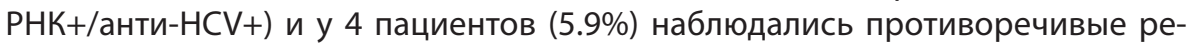
зультаты (анти-HCV+/HCV PHK-). Острая форма гепатита была установлена у одного пациента. Длительность проведения гемодиализа у HCV виремических пациентов была дольше, чем у авиремических пациентов ( $p=0.005)$.

Заключение: Настоящее исследование устанавливает, что HCV инфекция у диализных пациентов подлежит более точному диагностицированию при исследовании с применением двух диагностических методов - серологического теста и биомолекулярного анализа. Дополнительные исследования с применением выборки большего объёма могут доказать удачность применения данного подхода ко всем диализным пациентам в рамках страны. 